\title{
PEMBELAJARAN BERBASIS MASALAH UNTUK MENINGKATKAN KEMAMPUAN DAN DISPOSISI BERPIKIR KRITIS MATEMATIK SISWA SMA
}

\author{
Fiki Alghadari \\ Guru SMA Negeri Tanjungpandan Bangka Belitung \\ E-mail: alghar_6450@yahoo.com,alghar6450@gmail.com
}

\begin{abstract}
ABSTRAK
Latar belakang penelitian ini adalah pentingnya kemampuan dan disposisi berpikir kritis matematiksiswa, sedangkan tujuannya untuk mengetahuiperbedaan peningkatan kemampuan dan disposisi berpikir kritis matematik siswa yang mendapatkan pembelajaran berbasis-masalah dan pembelajaran konvensional. Penelitian ini merupakan penelitian eksperimen dengan disain kelompok kontrol non-ekivalen menggunakan teknik purposive sampling. Kelaseksperimen mendapat pembelajaran matematika berbasis-masalah dan kelas kontrol mendapat pembelajaran konvensional. Instrumen yang digunakan berupa tes kemampuan berpikir kritis, dan skala disposisi berpikir kritis. Penelitian ini dilakukan di salah satu sekolah menengah atas. Populasi penelitian ini adalah siswa SMA dengan sampel penelitian adalah siswa kelas X SMA Negeri di Tanjungpandan Bangka Belitung dengan responden penelitiannya adalah siswa kelas X sebanyak dua kelas yang dipilih secara acak dari enam kelas yang ada. Analisis data kemampuan dan disposisi berpikir kritis matematik menggunakan uji-t.Hasil penelitian menunjukkan bahwa peningkatan kemampuan berpikir kritis matematik siswa yang mendapat pembelajaran matematika berbasismasalah lebih baik daripada siswa yang mendapat pembelajaran konvensional. Analisis data skala memperlihatkan bahwa peningkatan disposisi berpikir kritis matematik siswa yang mendapatkan pembelajaran berbasis-masalah tidak lebih baik daripada siswa yang mendapat pembelajaran konvensional.Pembelajaran berbasis-masalah memungkinkan sebagai alternatif pembelajaran untuk diimplementasikan di SMA.
\end{abstract}

Kata Kunci: pembelajaran berbasis-masalah, kemampuan berpikir kritis matematik, disposisi berpikir kritis matematik

\begin{abstract}
Background on the research is important about mathematical critical thiking ability and disposition, while the research aims to know the improvement of students mathematical critical thinking abillity and disposition who obtain problem based learning and conventional learning. This research waseksperimen research with nonequivalent control group using purposive sampling technique. Eksperimen group received the mathematics problem based learning, and control group received the conventional learning. Instrumen was used a critical thinking ability, and a critical thinking scale. This research on the ones of senior high school.The research population is senior high school students, and first level students on senior high schoolTanjungpandan Bangka Belitung is the research sample. Research respondens is first levelas two groups who is randomly selected of six exsist groups.Data analysis of mathematical critical thinking ability and disposition used t-test. The results showed improvement students mathematical critical thinking abilityreceived the problem based learning better than students who received conventional learning. Data analysis of scale showed improvement students mathematical critical thinking disposition not better than students who received conventional learning. Problem based learning is enable as learning alternative for senior high school implemented.
\end{abstract}

Keywords: problem based learning, mathematical critical thinking ability, mathematical critical thinking disposition

\section{PENDAHULUAN}

Matematika merupakan pelajaran yang dapat menumbuhkembangkan berbagai kemampuan siswa. Kemampuan siswa untuk menemukan struktur dan konsep materi, sehingga dengan kemampuan tersebut siswa mampu berpikir matematik dan meningkatkan kemampuan lainya seperti yang termuat dalam National Council of Teachers of Mathematics (NCTM, 2000) yaitu problem solving, reasoning and proof, communication, connections, dan representation.

Kelemahan siswa pada kemampuan 
matematik ditandai dengan adanya kekeliruan pada penyelesaian masalah. Beberapa ahli menggolongkan jenis kesalahan yang sering dilakukan siswa yaitu; salah dalam menggunakan kaidah komputasi atau salah pemahaman konsep, kesalahan penggunaan operasi hitung, algoritma yang tidak sempurna, serta mengerjakan dengan serampangan (Widdiharto, 2008).Semua jenis kesalahan berawal dari pemahaman pada konsep matematik yang kurang dikuasai. Padahal dengan mengerjakan soal-soal latihan, maka pemahaman konsep akan semakin mantap (Krismanto, 2003). Namun, tetap percuma apabila siswa hanya berlatih mengerjakan soal tanpa memiliki pengetahuan dan pemahaman sebagai fondasi untuk memecahkan masalah.

Penelitian yang dilakukannya Sugandi (2010) menyimpulkan bahwa: faktor pendekatan pembelajaran lebih berperan daripada faktor tingkat kemampuan awal siswa, dan peringkat sekolah dalam menghasilkan kemampuan matematik tingkat tinggi siswa. Pembelajaran berbasis-masalah merupakan pendekatan pembelajaran yang diimplementasikan dalam penelitian tersebut.

Kemampuan matematik tingkat tinggi memang tidak setara dengan kemampuan berpikir kritis, tetapi semua komponen berpikir tingkat tinggi termuat dalam berpikir kritis (Sumarmo, dkk., 2012). Bercermin dari kesimpulan hasil studi Sugandi (2010), jika siswa belajar berdasarkan masalah akan meningkatkan pemahaman, makaakan terlihat perbedaan pada tingkat pengetahuan yang dimilikinya. Pengetahuan yang diperoleh akan dipahami secara mendalam karena PBM mendorong siswa sendiri yang melakukannya untuk: memperoleh pengetahuan dan pemahaman konsep, mencapai berpikir kritis, memiliki kemandirian belajar, keterampilan berpartisipasi dalam kerja kelompok, dan kemampuan pemecahan masalah (Sumarmo, dkk., 2012).
Ketika siswa berusaha memecahkan masalah, dibutuhkan kegigihan dalam menghadapi dan menyelesaikan masalah dengan gairah dan perhatian yang serius, tekun dalam mengerjakannya, rasa ingin tahu, dan percaya diri. Fleksibel dalam menggunakan pengetahuan dari berbagai disiplin ilmu, dan mencari metode penyelesaian alternatif juga tidak kalah penting dalam usaha menemukan penyelesaian masalah. Semua kebutuhan dalamusahamemecahkanmasalahmerupakan bagian indikator disposisi matematik yang dikemukakan Polking (Sumarmo, 2011). Lebih lanjut, juga merupakan ciri disposisi berpikir kritis yang ditelaah Ennis (Sumarmo, 2011), yaitu mencari berbagai alternatif, bersikap terbuka, dan bertindak cepat. Dengan demikian, pentingnya menggunakan disposisi matematik sekaligus disposisi berpikir kritis merupakan keutamaan dalam kehidupan sehari-hari untuk memecahkan masalah (Saurino, 2008).

Untuk keberhasilan dalam proses belajarmengajar penting bagi siswa memiliki pemahaman. Pemahaman merupakan kemampuan awal untuk mengembangkan berpikir kritis. Seperti hasil penelitian Prabawati (2011) bahwa terdapat korelasi yang positif antara pemahaman matematis dengan kemampuan berpikir kritis siswa. Sabandar (2007) juga mengutarakan bahwa kemampuan berpikir kritis adalah hasil cerminan pemecahan masalah. Jika disimpulkan, maka penting adanya inovasi dalam pembelajaran matematika untuk meningkatkan kemampuan berpikir kritis siswa, salah satunya pembelajaran berbasismasalah.

Berdasarkan uraian di atas, maka penelitian ini direncanakan untuk mengetahui efektivitas dan efisiensi pembelajaran berbasis-masalah jika dilihat pada peningkatan kemampuan dan disposisi berpikir kritis matematik siswa.

Masalah; Berdasarkan latar belakang, maka masalah yang dikaji dalam penelitian ini 
adalah: (1) Apakah pembelajaran berbasismasalah meningkatkan kemampuan dan disposisi berpikir kritis matematik siswa lebih baik daripada pembelajaran konvensional? (2) Adakah asosiasi antara kemampuan dan disposisi berpikir kritis matematik siswa yang belajar dengan pembelajaran berbasismasalah?

Tujuan penelitian; sejalan dengan rumusan masalah yang telah dikemukakan di atas, maka tujuan penelitian ini dilakukan adalah sebagai berikut:(1) Mengetahui pembelajaran berbasis-masalah dapat meningkatkan kemampuan dan disposisi berpikir kritis matematik siswa lebih baik daripada siswa yang belajar dengan pembelajaran konvensional. (2) Mengetahui ada tidaknya asosiasi antara kemampuan dan disposisi berpikir kritis matematik siswa yang belajar dengan PBM.

Kajian literatur dalam penulisan ini adalah:

\section{Pembelajaran Berbasis-Masalah}

Mencapai tujuan dan prinsip pembelajaran tidak cukup hanya dengan menggunakan rumus-rumus matematik dan memecahkan masalah rutin. Dibutuhkan inovasi pembelajaran matematika untuk meningkatkan pemahaman siswa. Salah satunya yaitu pembelajaran diawali dengan mengajukan masalah nyata dan kompleks, yang digunakan untuk memotivasi siswa melakukan identifikasi dan penyelidikan terhadap konsep dan prinsip belajar, kemudian siswa bekerja dalam kelompok kecil dengan masing-masing kemampuan kolektif yang dimiliki. Setelah pemecahan ditemukan, selanjutnya mengkomunikasikan, dan mengintegrasikan informasi (Duch, et al., 2001). Mengajukan masalah yang dirancang dalam konteks yang relevan dengan materi pelajaran, agar siswa memperoleh pengetahuan dan pemahaman konsep, mencapai berpikir kritis, memiliki kemandirian belajar, keterampilan berpartisipasi dalam kerja kelompok, dan kemampuan pemecahan masalah, itulah PembelajaranBerbasis-Masalah (Permana dan Sumarmo, 2007).

PBM merupakan pengembangan implementasi kurikulum atau strategi pembelajaran dengan menghadapkan siswa pada masalah yang kontekstual untuk dipecahkan secara konseptual.Masalah kontekstual diajukan untuk menuntun siswa secara aktif membangun pengetahuan baru berdasarkan pengalaman yang sudah dimiliki untuk menemukan pemahaman, yaitu merupakan bagian dari prinsip dalam pembelajaran matematika (Shadiq, 2008). Berikut ini disajikan langkah-langkah umum dalam menerapkan pembelajaran dengan PBM pada matematika seperti yang dikemukakan Ibrahim dan Nur (Permana dan Sumarmo, 2007; Sumarmo, dkk., 2012): (1) Mengorientasikan siswa pada masalah: guru memberi penjelasan tujuan pembelajaran, memotivasi siswa agar terlibat dalam kegiatan pemecahan masalah; (2) Mengorganisasikan siswa untuk belajar: guru membantu siswa mengidentifikasi dan mengorganisasi tugas belajar; (3) Membimbing pemeriksaan individual atau kelompok: guru mendorong siswa mengumpulkan informasi, melaksanakan eksperimen; (4) Mengembangkan dan menyajikan hasil karya: guru membantu siswa menyusun laporan dan berbagi tugas dengan sesama siswa; dan (5) Menganalisis dan mengevaluasi proses pemecahan masalah: guru membantu siswa merefleksi dan mengevaluasi proses yang telah dikerjakannya.

Berdasarkan langkah-langkah umum di atas, maka dapat diketahui beberapa ciri atau karakteristik PBM yaitu (Duch, et al., 2001; Sutawidjaja dan Dahlan, 2011; Permana dan Sumarmo, 2011): (1) Memulai pembelajaran dengan menyajikan masalah kontekstual. PBM mengedepankan pengalaman nyata untuk menemukan solusi yang nyata dari masalah yang diajukan, sehingga siswa memperoleh kebermaknaan sesuai 
pengalaman yang sebenarnya. Penyajian masalah kontekstual dalam bentuk yang tidak utuh atau tidak terstruktur (ill-structured) merupakan salah satu karakteristik PBM; (2) Berfokus pada interdisiplin. PBM menghadirkan masalah kontekstual kepada siswa, masalah akan dibuat semirip mungkin dengan kehidupan nyata sedemikian sehingga untuk siswa menyelesaikan masalah perlu melihat bidang-bidang ilmu pengetahuan lain sebagai referensi; (3) Penyelidikan otentik. PBM mengharuskan siswa melakukan penyelidikan untuk memecahkan masalah dengan mengikuti pertanyaan atau pernyataan sebagai pemandu siswa dalam menemukan solusi; (4) Menghasilkan produk. PBM membimbing siswa menemukan pemecahan dengan masing-masing pemahaman, sehingga dari setiap kelompok siswa memungkinkan akan menghasilkan cara pemecahan berbeda sebagai produk dari hasil interaksi pemikiran yang berkombinasi; dan (5) Kolaborasi. Interaksi dalam diskusi merupakan adaptasi intelektual yang berkonteks sosial. Siswa bekerja dalam kelompok atau berpasangan untuk menemukan pemecahan-masalah, sehingga solusi yang ditemukan merupakan hasil dari gabungan pola pikir siswa.

\section{Kemampuan Berpikir Kritis Matematik}

Kemampuan Berpikir Kritis (KBK)adalah berpikir yang masuk akal, reflektif, dan fokus pada apa yang diyakini (Ennis, 2011). Definisi berpikir kritis lebih tajam dikemukakan Glaser (Sumarmo, dkk., 2012) yaitu kemampuan dan disposisi yang menggabungkan pengetahuan awal, penalaran matematik, dan strategi kognitif untuk menggeneralisasi, membuktikan, dan mengevaluasi situasi matematik secara reflektif. Ennis dan Costa (Suryadi, 2001) mendifinisikan bahwa berpikir kritis merupakan suatu proses penggunaan kemampuan berpikir secara efektif yang dapat membantu seseorang untuk membuat, mengevaluasi, serta mengambil keputusan tentang apa yang diyakini atau dilakukan.

Langrehr (Sumarmo, 2011; Sumarmo, dkk.,
2012) juga menyampaikan pandangannya dalam bentuk definisi bahwa berpikir kritis merupakan berpikir evaluatifyang melibatkan kriteria yang relevan dalam mengases informasi disertai dengan ketepatan, relevansi, kepercayaan, ketegapan, dan bias.

Ennis (Sumarmo, 2011; Sumarmo, dkk., 2012), menyatakan beberapa indikator kemampuan berpikir kritis adalah: (1) memfokuskan diri pada pertanyaan, (2) menganalisis dan mengklarifikasi pertanyaan, jawaban, dan argumen, (3) mempertimbangkan sumber yang terpercaya, (4) mengamati dan menganalisis deduksi, (5) menginduksi dan menganalisis induksi, (6) merumuskan eksplanatori, kesimpulan dan hipotesis, (7) menarik pertimbangan yang bernilai, (8) menetapkan suatu aksi, dan (9) berinteraksi dengan orang lain.

Sedangkan menurut Glazer (2001), berpikir kritis memiliki tiga indikator yaitu: (1) Pembuktian, adalah kemampuan memberikan bukti deduktif (berdasarkan teori yang telah dipelajari) dari suatu pernyataan. (2) Generalisasi, adalah kemampuan untuk menemukan pola dari suatu persoalan yang dihadapi untuk kategori yang lebih luas. (3) Pemecahan masalah, adalah kemampuan mengidentifikasi unsur yang diketahui, mengetahui apa yang ditanyakan, memeriksa kecukupan unsur yang diperlukan dalam masalah, menyusun rencana penyelesaian, dan memeriksa kembali hasil atau jawaban yang diperoleh.

\section{Disposisi Berpikir Kritis Matematik}

Ketika siswa dihadapkan pada soal openended yang memiliki beberapa cara penyelesaian, siswa mengerjakannya dalam waktu yang ditentukan guru, maka dapat dipastikan bahwa kebanyakan siswa akan menyelesaikan dengan cara yang mudah dan cepat. Memilih cara penyelesaian yang mudah dan cepat ini adalah contoh sikap fleksibel dan berusaha mencari metode alternatif dalam memecahkan masalah. Sikap tersebut merupakan salah satu indikator disposisi matematik yang dikemukakan 
Polking (Sumarmo, 2011).Lebih lanjut, juga merupakan ciri dari disposisi berpikir kritis yang ditelaah Ennis (Sumarmo, 2011), yaitu mencari berbagai alternatif, bersikap terbuka, dan bertindak cepat.

Disposisi Berpikir Kritis (DBK) merupakan karakteristik dari pemikir kritis yang baik (Stedman and Andenoro, 2007). Halpern (1998) mendefinisikan disposisi berpikir kritis sebagai penggunaan kemampuan/ strategi untuk meningkatkan kemungkinan hasil yang diinginkan.

Disposisi berpikir kritis bisa dikembangkan dengan mengikuti beberapa karakteristik seperti yang dikemukakan Halpern (1998) berikut: (1) kesediaan untuk terlibat dan bertahan pada masalah yang kompleks, (2) kebiasaan menggunakan rencana dan penekanan aktivitas impulsif, (3) fleksibilitas atau keterbukaan pikiran, (4) kesediaan untuk meninggalkan strategi produktif dalam upaya untuk mengoreksi diri, dan (5) kesadaran akan realitas sosial yang perlu diatasi sehingga pikiran dapat menjadi tindakan. Dalam versi yang berbeda namun bermakna sama, hal tersebut juga dikemukakan oleh American Philosophical Association, bahwa pemikir kritis yang ideal tercermin dari kebiasaan ingin tahu, berpikiran terbuka, fleksibel, berpikiran adil dalam mengevaluasi, bijaksana dalam membuat keputusan, bersedia untuk mempertimbangkan kembali, rajin mencari informasi yang relevan, masuk akal dalam memilih kriteria, fokus gigih dalam penyelidikan (Facione, et al., 1995).

Dalam berpikir kritis terlibat disposisi berpikir yang dicirikan sebagai berikut: (1) bertanya secara jelas dan beralasan, (2) berusaha memahami dengan baik, (3) menggunakan sumber yang terpercaya, mempertimbangkan situasi secara keseluruhan, (4) berusaha tetap mengacu dan relevan ke masalah pokok, (5) mencari berbagai alternatif, (6) bersikap terbuka, (7) berani mengambil posisi, (8) bertindak cepat, (9) bersikap atau berpandangan bahwa sesuatu adalah bagian dari keseluruhan yang kompleks, (10) memanfaatkan cara berpikir orang lain yang kritis, dan (11) bersikap sensisif terhadap perasaan orang lain (Ennis, 2011; Sumarmo, 2011).

\section{METODE PENELITIAN}

Penelitian ini merupakan penelitian kuasi eksperimen dengan desain kelompok kontrol non-ekivalen (Ruseffendi, 2010). Subjek dalam penelitian ini adalah siswa di satu SMA Negeri di Tanjungpandan Bangka Belitung tahun pelajaran 2012/2013. Pengambilan sampel secara Purposive, sampel penelitiannya adalah siswa kelas eksperimen dengan jumlah 23 dan siswa kelas kontrol dengan jumlah 23. Instrumen yang digunakan dalam penelitian ini adalah tes kemampuan berpikir kritis dan skala disposisi berpikir kritis matematik.

\section{HASIL DAN PEMBAHASAN}

Pembahasan hasil penelitian ini berdasarkan pada faktor-faktor yang diamati dan ditemukan dalam penelitian.

\section{Peningkatan Kemampuan dan Berpikir Kritis Matematik}

Memperoleh data peningkatan kemampuan dan disposisi berpikir kritis matematik yaitu dengan menghitung n-gain atau gain ternormalisasi. Hasil peningkatan kemampuan dan disposisi berpikir kritis matematik siswa berdasarkan pembelajaran disajikan dalam Tabel 1.

Berdasarkan Tabel 1, diketahui bahwa ratarata peningkatan kemampuan berpikir kritis matematik siswa kelas pembelajaran berbasismasalah (PBM) lebih dari siswa kelas pembelajaran konvensional (PKV). Akan tetapi, rata-rata peningkatan kemampuan berpikir kritis matematik masih terbilang rendah walaupun berada dalam kategori sedang. Sedangkan rata-rata peningkatan disposisi berpikir kritis matematik siswa 
Tabel 1: Rata-rata dan Standar Deviasi n-Gain

Kemampuan dan Disposisi Berpikir Kritis

\begin{tabular}{|l|c|c|c|}
\hline \multirow{2}{*}{ Berpikir Kritis } & \multirow{2}{*}{ Kelompok } & \multicolumn{2}{c|}{ N-Gain } \\
\cline { 2 - 4 } & & Rata-rata & SD \\
\hline \multirow{2}{*}{ Kemampuan } & PBM & 0,354 & 0,104 \\
\cline { 2 - 4 } & PKV & 0,212 & 0,121 \\
\hline \multirow{2}{*}{ Disposisi } & PBM & 0,096 & 0,058 \\
\cline { 2 - 4 } & PKV & 0,142 & 0,175 \\
\hline
\end{tabular}

Catatan: skor ideal untuk KBK 20, DBK 104.

kelas PKV lebih dari kelas PBM.

Menjawab rumusan masalah, apakah kemampuan dan disposisi bepikir kritis matematik siswa kelas PBM lebih baik daripada kelas PKV, maka dilakukan uji perbedaan rata-rata peningkatan menggunakan Independent Samnle T-testdengan taraf signifikansi $\alpha=0,05$. Rangkuman hasil uji tersebut tertera dalam Tabel 2.

Tabel 2: Hasil Uji Perbedaan Rata-rata Peningkatan

Kemampuan dan Disposisi Berpikir Kritis

\begin{tabular}{|l|c|c|}
\hline \multicolumn{1}{|c|}{ Berpikir Kritis } & $\mathrm{t}$ & Sig. \\
\hline Kemampuan & 4,271 & 0,000 \\
\hline Disposisi & $-1,195$ & 0,242 \\
\hline
\end{tabular}

Berdasarkan Tabel 2, hasil uji perbedaan ratarata peningkatan kemampuan berpikir kritis matematik kedua kelomook siswa diperoleh nilai $\operatorname{sig}(p)=0,000<0,05=\alpha$ sehingga dapat disimpulkan bahwa kedua kelompok memiliki perbedaan kemampuan yang signifikan. Dengan demikian, PBM dapat meningkatkan kemampuan berpikir kritis matematik siswa lebih baik daripada PKV. Hasil uji perbedaan rata-rata peningkatan kemampuan berpikir kritis matematik, dan kesimpulan tersebut merupakan jawaban dari hipotesis penelitian yang diajukan.

Temuan mengenai perbedaan peningkatan kemampuan berpikir kritis matematik siswa antara kedua kelas dalam studi ini menyerupai hasil temuan studi yang dilakukan Prabawati (2011). Kemudian, kualifikasi peningkatan kemampuan berpikir kritis matematik siswa juga serupa, yaitu dalam tingkat yang sedang.

Sedangkan uji-t' untuk peningkatan disposisi berpikir kritis matematik diperoleh nilai probabilitas sig (2-tailed) yaitu 0,242 Nilai ini lebih besar dari taraf signifikansi 0,05 yang ditetapkan, sehingga hipotesis nol diterima. Dengan kata lain, peningkatan disposisi berpikir kritis siswa kelompok eksperimen tidak lebih baik daripada siswa kelompok kontrol. Hasil kesimpulan analisis data $n$-gain disposisi berpikir kritis matematik memberi jawaban negatif atas pertanyaan penelitian apakah PBM dapat meningkatkan disposisi berpikir kritis matematik siswa lebih baik daripada siswa yang belajar dengan PKV.

Temuan bahwa tidak terdapat perbedaan peningkatan disposisi berpikir kritis matematik hampir serupa dengan studi terdahulu yang dilakukan Sumarmo, dkk. (2012). Studi tersebut hanya menguji data posskala untuk mengetahui perbedaan disposisi berpikir kritis matematik siswa. Sedangkan dalam penelitian ini berbeda, yaitu menguji peningkatannya yang diperoleh dari data $n$-gain antara preskala dan posskala 
disposisi berpikir kritis.

\section{Asosiasi antara Kemampuan dan Disposisi Berpikir Kritis}

kemampuan dan disposisi berpikir kritis matematik dianalisis menggunakan uji korelasi Product Moment Pearson.

Mengetahui ada tidaknya asosiasi antara

Tabel 3

Hasil Uji Korelasi Kemampuan dan Disposisi Berpikir Kritis

\begin{tabular}{|c|c|c|}
\hline Pearson & Sig. (2-tailed) & Simpulan \\
\hline 0,170 & 0,439 & Terima $H_{0}$ \\
\hline
\end{tabular}

Berdasarkan Tabel 3, diperoleh koefisien korelasi product momen antara kemampuan dan dicnncici berpikir kritis siswa sebesar $r_{x y}=0,170$ dan nilai sig $(p)=0.439>0,05=\alpha$, sehingga hipotesis nol diterima. Dengan kata lain dapat disimpulkan bahwa tidak terdapat hubungan antara kemampuan dan disposisi berpikir kritis matematik siswa melalui PBM.

Temuan bahwa tidak ada asosiasi antara kemampuan dan disposisi berpikir kritis matematik dalam penelitian ini sama dengan hasil studi Sumarmo, dkk. (2012) dan studi Rimiene (2002).

\section{KESIMPULAN}

Berdasarkan hasil pengolahan data, analisis, dan pembahasan didapatkan kesimpulan sebagai berikut: (1) Peningkatan kemampuan berpikir kritis matematik siswa SMA yang belajar dengan PBM lebih baik daripada siswa yang belajar dengan PKV; (2) Tidak terdapat perbedaan peningkatan disposisi berpikir kritis matematik siswa SMA yang belajar dengan PBM lebih baik daripada siswa yang belajar dengan PKV; dan (3) Tidak terdapat asosiasi antara kemampuan dan disposisi berpikir kritis matematik siswa yang belajar dengan PBM.

Adapun, dari hasil penelitian ini penulis merekomendasikan beberapa hal, antara lain: (1) PBM disarankan untuk dilakukan pada pokok bahasan tertentu yang relevan untuk lebih dipahami secara mendalam sesuai eksplorasi konsep yang mereka lakukan secara kolaborasi; (2) Proses implementasi PBM pada siswa SMA, sebaiknya memperhatikan kemampuan dan taraf pemahaman siswa dalam matematika, waktu pertemuan untuk belajar di kelas, jumlah siswa dalam kelompok diskusi, dan kemampuan siswa dalam kelompok diskusi harus yang heterogen; dan (3) Pentingnya menemukan asosiasi antara kemampuan dan disposisi berpikir kritis matematik dikarenakan kedua variabel tersebut memiliki hubungan yang erat kaitannya satu sama lain. Ketidakberhasilan peneliti menemukan hasil uji korelasi yang signifikan kembali membuka peluang pada peneliti lanjutan.

\section{DAFTAR PUSTAKA}

Duch, B.J., Groh, E. and Allen, D.E. (2001).The Power of Problem-Based Learning. Sterling, Virginia: Stylus Publishing, LLC.

Halpern, D.E. (1998). Teaching Critical Thinking for Transfer Across Domains: Dispositions, Abilitys, Structure Training, and Metacognitive Monitoring. Dalam American Psychological Association.Vol. 53. (4). [Online]. Tersedia: http://projects.ict.usc.edu/itw/vtt/HalpernAmPsy98CritThink.pdf [24 Februari 2013]

Krismanto, A. (2003). Beberapa Teknik, Model, Dan Strategi Dalam Pembelajranan Matematika. Yogyakarta: DEPDIKNAS.

NCTM. (2000). Principles and Standards for Schools Mathematics. Reston, VA: NCTM Inc. 
Permana, Y. dan Sumarmo, U. (2007). Mengembangkan Kemampuan Penalaran dan Koneksi Matematik Siswa SMA melalui Pembelajaran Berbasis Masalah. Dalam Educationist. Vol. 1 (2).

Prabawati, M.N. (2011). Pengaruh Penggunaan Pembelajaran Kontekstual Teknik SQ3R Terhadap Peningkatan Kemampuan Pemahaman dan Berpikir Kritis Matematik Siswa. Tesis Pendidikan Matematika UPI: Tidak dipublikasikan.

Rimiene, V. (2002). Assessing and developing students' critical thinking. Dalam Psychology Learning and Teaching, Vol. 2(1), 17-22. [Online]. Tersedia: http:/www.heacademy.ac.uk/assets/documents/subjects/ psychology/2-1-rimiene.pdf [25 Februari 2013]

Ruseffendi, E.T.(2010). Dasar-dasar Penelitian Pendidikan dan Bidang Noneksakta Lainnya. Bandung: Tarsito.

Sabandar, J. (2007). Berpikir Reflektif dalam Pembelajaran Matematika. Pendidikan Matematika UPI: Tidak dipublikasikan.

Saurino, D.R. (2008). Concept Journaling to Increase Critical Thinking Dispositions and Problem Solving Abilitys in Adult Education. Dalam The Journal of Human Resource and Adult Learning. Vol. 4 (1).[Online]. Tersedia: http://www.hraljournal.com/Page/19\%20Dan\%20R. \%20Saurino.pdf [22 Februari 2013]

Shadiq, F.(2008).Psikologi Pembelajaran Matematika di SMA. Yogyakarta: DEPDIKNAS. . (2009). Kemahiran Matematika. Yogyakarta: DEPDIKNAS.

Stedman, N.L.P. dan Andenoro, A.C. (2007).Identification of Relationships between Emotional Intelligence Ability\& Critical Thinking Disposition in Undergraduate Leadership Students.Dalam Journal of Leadership Education.Vol. 6 (1).[Online]. Tersedia: http://www.leadershipeducators. org/Resources/ Documents/jole/2007_winter/Jole_6_1_Stedman_Andenoro.pdf [26 Februari 2013]

Sugandi, A.I. (2010). Pengaruh Pembelajaran Berbasis-Masalah dengan Setting Kooperatif Tipe Jigsaw terhadap Pencapaian Kemampuan Matematik Tingkat Tinggi dan Kemandirian Belajar Siswa SMA. Disertasi Pendidikan Matematika UPI: Tidak dipublikasikan.

Sumarmo, U. (2011). Pendidikan Karakter dan Pengembangan Kemampuan Berpikir dan Disposisi Matematik serta Pembelajarannya.Dalam Kumpulan Makalah Berpikir dan Disposisi Matematik serta Pembelajarannya Jurusan Pendidikan Matematika FMIPA UPI.

Sumarmo, U., Hidayat, W., Zulkarnaen, R., Hamidah, dan Sariningsih, R. (2012). Kemampuan dan Disposisi Berpikir Logis, Kritis, dan Kreatif Matematik.Dalam Kumpulan Makalah Berpikir dan Disposisi Matematik serta Pembelajarannya Jurusan Pendidikan Matematika FMIPA UPI.

Suryadi, D. (2001). Penggunaan Pendekatan Pembelajaran Tidak Langsung serta Pendekatan Gabungan Langsung dan Tidak Langsung dalam Rangka Meningkatkan Kemampuan Berpikir Matematik Tingkat Tinggi Siswa SLTP. Disertasi Pendidikan Matematika UPI: Tidak dipublikasikan.

Sutawidjaja, A dan Dahlan, J.A. (2011).Pembelajaran Matematika. Jakarta: UT.

Widdiharto, R. (2008). Diagnosis Kesulitan Belajar Matematika SMP dan Alternatif Proses Remidinya. Yogyakarta: DEPDIKNAS. 